\section{Anti-Helicobacter pylori activity and oxidative burst inhibition by the naphthoquinone 5-methoxy-3,4-dehydroxanthomegnin from Paepalanthus latipes}

\author{
Rodrigo Rezende Kitagawa, ${ }^{* 1}$ Cibele Bonacorsi, ${ }^{2}$ Luiz Marcos \\ da Fonseca, ${ }^{2}$ Wagner Vilegas, ${ }^{3}$ Maria Stella Gonçalves Raddi ${ }^{2}$
}

\author{
${ }^{1}$ Departamento de Ciências Farmacêuticas, Universidade Federal do Espírito Santo, \\ Brazil, \\ ${ }^{2}$ Faculdade de Ciências Farmacêuticas de Araraquara, Universidade Estadual \\ Paulista "Júlio de Mesquita Filho", Brazil, \\ ${ }^{3}$ Instituto de Química de Araraquara, Universidade Estadual Paulista "Júlio de \\ Mesquita Filho", Brazil.
}

Revista Brasileira de Farmacognosia Brazilian Journal of Pharmacognosy 22(1): 53-59, Jan./Feb. 2012

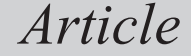

Received 11 Apr 2011 Accepted 1 Jul 2011 Available online 21 Oct 2011

Keywords: 5-methoxy-3,4-dehydroxanthomegnin Helicobacter pylori oxidative burst Paepalanthus latipes

ISSN 0102-695X http://dx.doi.org/10.1590/S0102$695 \times 2011005000193$

\section{Introduction}

Helicobacter pylori is a spiral-shaped bacterium that colonizes the stomach in $50 \%$ of the world's population (Stege et al., 2006). H. pylori infection is recognized as an important causative agent of gastroduodenal diseases, including chronic gastritis, peptic ulceration, gastric adenocarcinoma, and gastric lymphoma (Park et al., 2006; Ding et al., 2007; Wang et al., 2008; Pastene et al., 2009). Studies have shown an association between long-term infection with $H$. pylori and the development of gastric adenocarcinoma. The World Health Organization has classified H. pylori as a group I carcinogen, with an attributable risk for gastric cancer of 50-60\% (Smoot et al., 2000). This bacterium induces inflammation, infiltration and activation of immune cells, accumulation of reactive oxygen species, and oxidative DNA damage in the gastric mucosa (Ernst, 1999; Bagchi et al., 2002; Arend et al., 2005). A characteristic feature of this infection is the pronounced and sustained accumulation of neutrophils in the gastric mucosa (Allen \& McCaffrey, 2007). The results of several studies indicate that $H$. pylori can activate neutrophils in vitro. Moreover, neutrophil density in vivo correlates directly with the ability of $H$. pylori to cause severe disease, and the available data suggest that neutrophils and bacteria act in concert to induce gastric ulceration (Allen et al., 2005). Eradication of the organism has been shown to result in ulcer healing and prevention of peptic ulcer recurrence and may also reduce the prevalence of gastric cancer in high-risk populations (Zaidi et al., 2009). 
Treatment of $H$. pylori infection consists of 1-2 weeks of 1 or 2 effective antibiotics, including amoxicillin, tetracycline, metronidazole, or clarithromycin, plus ranitidine bismuth citrate, bismuth subsalicylate, or a proton pump inhibitor (Howden \& Hunt, 1998; Duynhoven \& Jonge, 2001; Park et al., 2006). However, this triple therapy is not always successful in eradicating the infection, and the acquisition of antibiotic resistance by $H$. pylori could reduce treatment efficacy and present a serious problem (Bonacorsi et al., 2009). As eradication therapies can be ineffective and undesirable side effects may occur, the search for new drugs for use in alternative therapies is very important (Stege et al., 2006; Zaidi et al., 2009).

In the course of this search, a number of different products from the plant kingdom have been tested, including antimicrobials belonging to different phytochemical groups (Pastene, 2009).

Quinone derivatives are ubiquitous in nature, having been found in plants, fungi, and bacteria, and are associated with antitumor, antibacterial, antimalarial, and antifungal activities (Huang et al., 2002). 5-Methoxy-3,4-dehydroxanthomegnin (1), a 1,4-naphthoquinone isolated from the capitula of the Paepalanthus latipes Silv. plant belonging to the Eriocaulaceae family, previously, showed a significant cytotoxic index (CI) for McCoy cells compared with cisplatin (Kitagawa et al., 2004).

The purpose of the present study was to investigate both the anti- $H$. pylori activity of this naphthoquinone, and its ability to act as an antioxidant by interfering with the neutrophil respiratory burst.

\section{Material and Methods}

\section{Plant material}

Paepalanthus latipes Silv., Eriocaulaceae, was collected at Serra do Cipó in the Espinhaço Chain, Minas Gerais, Brazil, and authenticated by Prof. Paulo Takeo Sano from Instituto de Biociências, USP, São Paulo. The voucher specimen (CFSC 13846) is on file of the Herbarium in the Departamento de Botânica, Instituto de Biociências, Universidade de São Paulo, Brazil.

\section{Chemicals}

Dimethyl sulfoxide (DMSO) (D8779), luminol (5-amino-2,3-dihydro-1,4-phthalazinedione) sodium salt (A4685), lucigenin (M8010), zymosan A (Z4250), phorbol myristate acetate (PMA) (P8139), glycogen type II from oyster (G8751), RPMI (R7755), and MTT-tetrazolium (M2128) were purchased from Sigma (St. Louis, MO, USA), and Ficoll-Paque Plus d
1077 (17-1440-02) from Pharmacia Biotech (Sweden). 5-Methoxy-3,4-dehydroxanthomegnin (1) was isolated from $P$. latipes and characterized as previously described (Kitagawa et al., 2004) and stored as a stock solution of $10.0 \mathrm{mg} / \mathrm{mL}$ in DMSO. Eagle medium (Adolf Lutz Institute) with various concentrations of DMSO was used in the experiments. The highest final concentration of DMSO used $(2 \%)$ does not interfere with cell viability.<smiles>COC1=CC(=O)c2c(c(O)c3c(=O)oc(C)cc3c2OC)C1=O</smiles>

1

\section{Bacterial strain}

H. pylori ATCC 43504, which is resistant to metronidazole (MtzR) and susceptible to amoxicillin (AmxS), was obtained from the American Type Culture Collection (Manassas, VA, USA). The bacteria were cultured in Columbia agar containing 5\% sheep blood at $36-37{ }^{\circ} \mathrm{C}$, in a $5 \% \mathrm{O}_{2}, 10 \% \mathrm{CO}_{2}, 85 \% \mathrm{~N}_{2}$ atmosphere for three days.

\section{Antimicrobial activity}

Brain heart infusion (BHI) broth (100 $\mu \mathrm{L}$ ) (supplemented with $10 \%$ fetal bovine serum) containing various concentrations of 5-methoxy-3,4dehydroxanthomegnin $(4-1024 \mu \mathrm{g} / \mathrm{mL})$ was added to the wells of a 96-well microplate. The same volume of $H$. pylori suspension (about $10^{6} \mathrm{cfu} / \mathrm{mL}$ in BHI) was added to each well. The absorbance at $620 \mathrm{~nm}$ was determined using an automatic ELISA microplate reader (Spectra \& Rainbow Readers, Tecan). The microplate was incubated at $36-37{ }^{\circ} \mathrm{C}$ under a microaerophilic atmosphere for $72 \mathrm{~h}$ and then agitated before the absorbance was read again at the same wavelength. The pre- and post-incubation absorbance values were compared to determine the amount bacterial growth. The lowest concentration of 5-methoxy-3,4-dehydroxanthomegnin (1) that inhibited bacterial growth at least $90 \%$ was designated as the minimal inhibitory concentration (MIC). All experiments were performed at least three times using three wells for each concentration of the tested chemical. Amoxicillin and metronidazole were used as reference antimicrobials.

The minimal bactericidal concentration (MBC) was determined by culturing one standard loop from each well with no apparent growth in BHI and 
incubating at $37^{\circ} \mathrm{C}$ for $72 \mathrm{~h}$. The lowest concentration that inhibited colony formation on Columbia agar plates containing 5\% sheep blood was designated as the MBC for the tested compound.

\section{Animals}

Male rats (Rattus norvegicus albinus) weighing 190-200 g were obtained from Faculdade de Ciências Farmacêuticas, Universidade Estadual Paulista, Araraquara, SP, Brazil, and maintained in a polycarbonate box (at $23 \pm 1{ }^{\circ} \mathrm{C}, 55 \pm 5 \%$ humidity, 10 18 air changes $/ \mathrm{h}$, and a 12 -h light/dark cycle) with free access to water and standard rodent chow. All animals were maintained and handled according to the International Ethical Guidelines for the Care of Laboratory Animals (Faculty Ethics Committee \# 06/2005).

\section{Peritoneal neutrophils collection}

Rat peritoneal neutrophils were obtained by injecting each rat intraperitoneally with $10 \mathrm{~mL}$ of oyster glycogen solution $(0.5 \% \mathrm{w} / \mathrm{v})$. Peritoneal exudates were collected $12 \mathrm{~h}$ post-injection in Dulbecco's phosphatebuffered saline without calcium (PBS-D) containing 10 $\mathrm{IU} / \mathrm{mL}$ heparin. The cells were washed twice, carefully layered onto $5 \mathrm{~mL}$ of Ficoll-Paque, and centrifuged for $30 \mathrm{~min}$ at $700 \times \mathrm{g}$. The neutrophils were washed twice in Dulbecco's phosphate-buffered saline (PBS) and adjusted to a concentration of $1.0 \times 10^{6}$ cells $/ \mathrm{mL}$. This procedure yielded a preparation containing $95 \%$ neutrophils, which were $98 \%$ viable as measured by the MTT-tetrazolium assay (Freshney, 1994; Mosmann, 1983).

Effect of 5-methoxy-3,4-dehydroxanthomegnin on neutrophil viability

Ninety-six-well tissue culture plates were seeded with $100 \mu \mathrm{L} /$ well of RPMI containing approximately $6 \times 10^{6}$ cells $/ \mathrm{mL}$ and incubated at $37^{\circ} \mathrm{C}$. After $1 \mathrm{~h}$, the RPMI was removed and the cells were treated with different concentrations of 5-methoxy3,4-dehydroxanthomegnin $(2-128 \mu \mathrm{g} / \mathrm{mL})$ in PBS-D. After $1 \mathrm{~h}$, the medium was removed and the plates were prepared for the MTT-tetrazolium assay. The plates were agitated briefly and transferred to a microplate reader (Spectra \& Rainbow (Shell) Readers, Tecan, Austria), and the optical density of each well was measured using a $540 \mathrm{~nm}$ filter and a $620 \mathrm{~nm}$ reference wavelength. All experiments were performed at least four times using three wells for each concentration of the tested chemical. The cytotoxicity data were standardized by determining the absorbance values and calculating the corresponding chemical concentrations. Linear regression analysis with $95 \%$ confidence limits was used to define the doseresponse curve and compute the cytotoxic midpoint (IC50), the concentration required to obtain a 50\% decrease in the spectrophotometric absorbance relative to that of the control (Barile, 1994). This test allowed us to determine the viability of neutrophils after a $1 \mathrm{~h}$ incubation with different concentrations of 5-methoxy3,4-dehydroxanthomegnin.

\section{Chemiluminescence assay}

Chemiluminescence was measured on a BioOrbit model 1251 luminometer (Turku, Finland) using polypropylene tubes containing $1.0 \mathrm{~mL}$ of the reaction mixture. Briefly, neutrophils at $1.0 \times 10^{6}$ cells/ $\mathrm{mL}$ were mixed with $2 \times 10^{-5} \mathrm{M}$ luminol or $2 \times 10^{-5} \mathrm{M}$ lucigenin in PBS-D. The mixtures were incubated for $10 \mathrm{~min}$ at $37{ }^{\circ} \mathrm{C}$ and then mixed thoroughly with $0.7 \mathrm{mg} / \mathrm{mL}$ non-opsonized zymosan or $3 \times 10^{-7}$ $M$ PMA and PBS-D containing 5-methoxy-3,4dehydroxanthomegnin at non-cytotoxic concentrations $(0.6,1.2,2.5,5,10$ and $20 \mu \mathrm{g} / \mathrm{mL})$. The background signals were measured in the absence of stimulants or 5-methoxy-3,4-dehydroxanthomegnin. The luminoland lucigenin-enhanced chemiluminescence values were calculated using Multiuse 2.0 software (BioOrbit, Turku, Finland). The chemiluminescence response was quantified as the integrated area (IA) below the resulting chemiluminescence curve from 0 to $40 \mathrm{~min}$ for luminol chemiluminescence and from 0 to $15 \mathrm{~min}$ for lucigenin chemiluminescence. The values were compared to those of the control curve obtained without 5-methoxy-3,4dehydroxanthomegnin, i.e., cells/luminol or lucigenin/ stimulants.

The ED50, i.e., dose of 5-methoxy-3,4dehydroxanthomegnin producing $50 \%$ inhibition of the control chemiluminescence, was calculated using a log-plot transformation of the data.

\section{Reaction with hypochlorous acid}

The reaction with $\mathrm{HOCl}$ was studied using the method of Ching et al. (1994) based on the oxidation of 5-thio-2-nitrobenzoic acid (TNB). TNB was obtained by reducing a $1 \mathrm{mM}$ solution of 5,5'-dithiobis(2nitrobenzoic acid) (DTNB) in a buffer containing 50 $\mathrm{mM} \mathrm{KH} \mathrm{PO}_{4}-\mathrm{KOH}, \mathrm{pH} 6.6,5 \mathrm{mM}$ EDTA, and $20 \mathrm{mM}$ sodium borohydride. For the assay, $25 \mu \mathrm{M} \mathrm{HOCl}$ was incubated with $50 \mu \mathrm{M}$ TNB for $5 \mathrm{~min}$ in the presence or absence of 5-methoxy-3,4-dehydroxanthomegnin in a final volume of $1 \mathrm{~mL}$. The HOCl-scavenging ability of the 5-methoxy-3,4-dehydroxanthomegnin was determined by measuring the oxidation of TNB to DTNB at $412 \mathrm{~nm}$ after pre-incubating the 5-methoxy- 
3,4-dehydroxanthomegnin with $\mathrm{HOCl}$ and then adding TNB.

\section{Statistical analysis}

The parameters were expressed as the mean (SD). Data were analyzed by analysis of variance (ANOVA), and a $p<0.05$ was considered statistically significant.

\section{Results and Discussion}

Helicobacter pylori has been implicated in the pathogenesis of gastritis, peptic ulceration, and possibly neoplasia (Allen et al., 2005). Antibacterial treatment of $H$. pylori is difficult due to the organism's location beneath the layer of mucus adherent to the gastric mucosa. Penetration of antibacterial agents to this site from either the lumen of the stomach or the gastric blood supply is limited. The $\mathrm{pH}$ of gastric secretions and sites within the mucosa may also affect drug activity (Park et al., 2006).

However, $H$. pylori antibiotic resistance is thought to be the most important factor in eradication failure. Resistance rates are highest for metronidazole (19.9-39.2\%), followed by clarithromycin (1.727.7\%), and lowest for amoxicillin, tetracycline, and trovafloxacin (0-4.7\%) (Wang et al., 2009).

In addition, antibiotic treatments have had undesirable effects on non-target organisms such as intestinal microorganisms and have sometimes caused serious side effects, including diarrhea, nausea, abnormal taste, dyspepsia, abnormal pain/discomfort, headache, and angioedema (Park et al., 2006). Therefore, the increasing difficulties of standard treatment posed by antibiotic resistance, adverse effects, and high cost have led researchers to explore natural products as alternative sources of antimicrobials (Zaidi et al., 2009).

Plants, particularly higher plants, are rich sources of bioactive chemicals and may therefore be alternative sources of materials for $H$. pylori eradication (Park et al., 2006). The antimicrobial compounds from plants may inhibit bacterial growth by different mechanisms than those of presently used antimicrobials and could therefore be of clinical value in the treatment of antibiotic-resistant microbial strains, including $H$. pylori (Bonacorsi et al., 2009). Many anti-H. pylori compounds exhibiting significant inhibitory effects including flavonoids, tannins, terpenes, aromatic aldehydes, alcohols, catechins, and quinones, have been identified from plant materials (Funatogawa et al., 2004; Nostro et al., 2005; Shin et al., 2005; Park et al., 2006).

Quinones are ubiquitous in nature and are characteristically highly reactive. In addition to providing a source of stable free radicals, quinones are known to combine irreversibly with nucleophilic amino acids in proteins, often leading to protein inactivation and loss of function. Therefore, the potential range of quinone antimicrobial effects is great. Probable targets in the microbial cell are surface-exposed adhesins, cell wall polypeptides, and membrane-bound enzymes. Quinones may also render substrates unavailable to the microorganism (Cowan, 1999).

In the present study, the naphthoquinone 5-methoxy-3,4-dehydroxanthomegnin (1) showed selective anti- $H$. pylori activity with an MIC value of $64 \mu \mathrm{g} / \mathrm{mL}$ and an MBC of $128 \mu \mathrm{g} / \mathrm{mL}$. The antibacterial activity of 5-methoxy-3,4-dehydroxanthomegnin against $H$. pylori measured by spectrophotometer microdilution assay is shown in Figure 1. The anti- $H$. pylori activity of the isolated compound was more potent than that of metronidazole (MIC $>254 \mu \mathrm{g} / \mathrm{mL}$ ) but less than that of amoxicillin (MIC $2 \mu \mathrm{g} / \mathrm{mL}$ ). However, the MBC of amoxicillin for $H$. pylori could not be measured. These data demonstrated that 5-methoxy3,4-dehydroxanthomegnin exhibited promising activity against $H$. pylori.

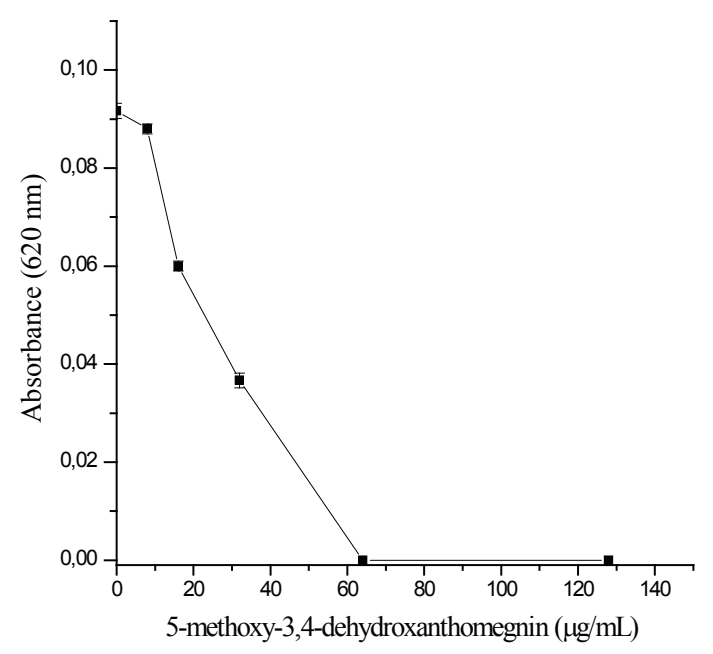

Figure 1. Effect of 5-methoxy-3,4-dehydroxanthomegnin on growth of Helicobacter pylori after incubation for $72 \mathrm{~h}$.

H. pylori infection of the gastric mucosa is associated with an abundant inflammatory response (Smoot et al., 2000). Studies have shown that H. pylori stimulates a strong respiratory burst in neutrophils that exceeds that produced by other bacteria (such as Staphylococcus aureus and Salmonella) on a per organism basis and is comparable in magnitude to that induced by the large yeast cell wall particle zymosan. Neutrophils containing as few as $12 \mathrm{H}$. pylori organisms consume as much oxygen as cells stimulated with the 
potent neutrophil agonist PMA. However, H. pylori disrupts NADPH oxidase targeting such that ROS are generated in the extracellular space and do not accumulate inside $H$. pylori-containing phagosomes or at other intracellular sites. H. pylori thus evades oxidative killing, while neutrophil-derived oxidants induce severe host tissue damage and ulceration (Allen et al., 2005; Allen \& McCaffrey, 2007).

Therefore, a new therapeutic approach to treatment of $H$. pylori-associated gastric mucosal inflammation has been proposed, using agents that inhibit ROS production by activated neutrophils or scavenge the ROS produced (Naito \& Yoshikawa, 2002).

Pro-and antioxidants can be studied in biological systems using methods such as chemiluminescence assays that measure the production of ROS (including peroxyl radicals, $\mathrm{OH}$., $\mathrm{HOCl}, \mathrm{H}_{2} \mathrm{O}_{2}$, and $\mathrm{O}_{2}-$, among others) (Yildiz \& Demiryürek, 1998; Prior \& Cao, 1999).

Chemiluminescence has been widely used as a sensitive assay for monitoring free radicals and reactive metabolites produced by enzymes, cells, or organ systems (Yildiz \& Demiryürek, 1998). The chemiluminescence assay allows continual monitoring of ROS throughout different metabolic stages by using different chemiluminescent probes. The use of probes such as luminol and lucigenin-amplifies chemiluminescence by allowing the detection of low levels of light emission, thereby increasing the sensitivity of the reaction (Trush, 1987; Stites, 1994). Several studies have suggested that light emissions from different chemiluminescent probes represent different ROS in different cellular compartments. For example, luminol tracks the production of reactive oxygen species formed in the intra- and extracellular environment, such as $\mathrm{HOCl}, \mathrm{H}_{2} \mathrm{O}_{2}, \mathrm{O}_{2}^{-}$, and ${ }^{1} \mathrm{O}_{2}$, while lucigenin, being membrane-impermeable, tracks the production of extracellular $\mathrm{O}_{2}^{-}$(Parij et al ., 1998). An antioxidant reduces or prevents ROS oxidation of the substrate (probe), resulting in decreased chemiluminescence (Hirayama et al., 1997).

Significant inhibition of the intensity of luminol- and lucigenin-enhanced chemiluminescence in stimulated neutrophils by 5-methoxy-3,4dehydroxanthomegnin was observed (Figures 2, 3). Our results showed that 5-methoxy-3,4dehydroxanthomegnin is able to modulate the phagocyte respiratory burst in a dose-dependent manner, with ED50 values of $1.58 \pm 0.09 \mu \mathrm{g} / \mathrm{mL}$ and $5.4 \pm 0.15 \mu \mathrm{g} / \mathrm{mL}$ for luminol- and lucigenin-enhanced chemiluminescence, respectively. In the MTT cytotoxicity assay, the neutrophil viability remained above $90 \%$ in the presence of all tested concentrations of 5-methoxy-3,4-dehydroxanthomegnin for a period of 1 $\mathrm{h}$ (data not shown). Therefore, there is a large difference in the dose-dependency of the protective effects and cytotoxicity of 5-methoxy-3,4-dehydroxanthomegnin for neutrophils. This decrease in the luminol- and lucigenin-amplified chemiluminescence is probably due to an inhibitory effect on one or more reactive oxygen-generating systems, such as the $\mathrm{MPO} / \mathrm{H}_{2} \mathrm{O}_{2} / \mathrm{Cl}_{2}$ and/or NADPH oxidase complexes.

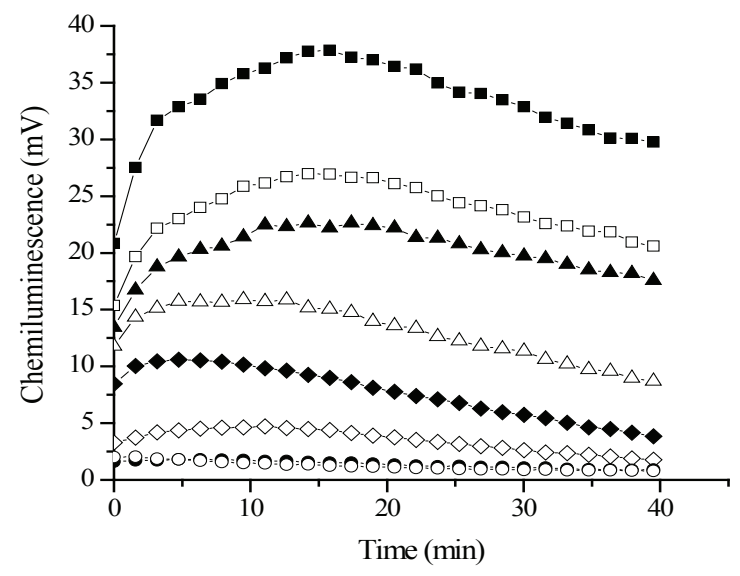

Figure 2. Influence of different doses of 5-methoxy-3,4dehydroxanthomegnin on non-opsonized zymosan-induced chemiluminescence of polymorphonuclear neutrophils. Reactive oxygen species (ROS) production in neutrophils (1.0 $\times 10^{6}$ cells $\left./ \mathrm{mL}\right)$ is represented kinetically as millivolt $(\mathrm{mV})$ values detected by luminol-enhanced chemiluminescence assay. ROS production in the cells treated with non-opsonized zymosan only as a control (solid rectangles) or phosphatebuffered saline without calcium (PBS-D) only to measure the background (open circles) was measured from 0 to $40 \mathrm{~min}$ post-treatment. The cells were treated with 5-methoxy-3,4dehydroxanthomegnin at $0.6 \mu \mathrm{g} / \mathrm{mL}$ (open rectangles), 1.2 $\mu \mathrm{g} / \mathrm{mL}$ (solid triangles), $* 2.5 \mu \mathrm{g} / \mathrm{mL}$ (open triangles), ${ }^{*} 5 \mu \mathrm{g} /$ $\mathrm{mL}$ (solid diamonds), ${ }^{*} 10 \mu \mathrm{g} / \mathrm{mL}$ (open diamonds)* and 20 $\mu \mathrm{g} / \mathrm{mL}$ (solid circles). ${ }^{*} p<0.05$.

Myeloperoxidase catalytic activity is complex and involves two distinct pathways: myeloperoxidase has $\mathrm{HOCl}$ generation activity in addition to its regular peroxidase activity (Kitagawa et al., 2003). We investigated the scavenger effect of 5-methoxy-3,4dehydroxanthomegnin on $\mathrm{HOCl}$ using the TNB test, where oxidation of TNB by $\mathrm{HOCl}$ results in a loss of absorbance at $412 \mathrm{~nm}$. Any $\mathrm{HOCl}$ scavenger present in the system will compete with TNB for $\mathrm{HOCl}$ and limit the change in absorbance at $412 \mathrm{~nm}$ (Marshall et al., 1996). Incubation of $\mathrm{HOCl}$ with 5-methoxy3,4-dehydroxanthomegnin before the addition of TNB did not diminish the amount of TNB oxidized, indicating that 5-methoxy-3,4-dehydroxanthomegnin does not react with $\mathrm{HOCl}$ (Table 1). Therefore, it seems that the inhibitory activity of 5-methoxy- 
3,4-dehydroxanthomegnin on luminol-enhanced chemiluminescence is a consequence of interference with the enzymatic system rather than scavenging activity.

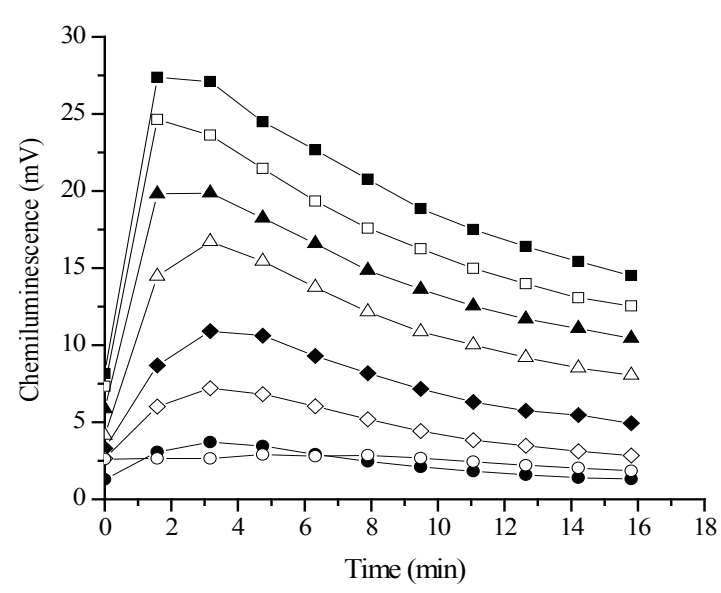

Figure 3. Effect of 5-methoxy-3,4-dehydroxanthomegnin on phorbol myristate acetate (PMA)-stimulated lucigeninenhanced chemiluminescence of polymorphonuclear neutrophils. Superoxide production in cells treated with PMA only as a control (solid rectangles) or with PBS-D only to measure the background (open circles) was measured from 0 to $15 \mathrm{~min}$ post-treatment. The cells were treated with 5-methoxy-3,4-dehydroxanthomegnin at $0.6 \mu \mathrm{g} / \mathrm{mL}$ (open rectangles), $1.2 \mu \mathrm{g} / \mathrm{mL}$ (solid triangles), $2.5 \mu \mathrm{g} / \mathrm{mL}$ (open triangles), * $5 \mu \mathrm{g} / \mathrm{mL}$ (solid diamonds), ${ }^{*} 10 \mu \mathrm{g} / \mathrm{mL}$ (open diamonds) ${ }^{*}$ and $20 \mu \mathrm{g} / \mathrm{mL}$ (solid circles). ${ }^{*} p<0.05$.

Table 1. Effect of 5-methoxy-3,4-dehydroxanthomegnin on HOCl-dependent TNB oxidation.

\begin{tabular}{lc}
\hline \multicolumn{1}{c}{ Additions } & $\mathrm{A} 412^{\mathrm{a})}$ \\
\hline None & 0.473 \\
$\mathrm{HOCl}$ & 0.097 \\
$\mathrm{HOCl}$ and 5-methoxy-3,4-dehydroxanthomegnin \\
\hline $5 \mu \mathrm{g} / \mathrm{mL}$ & 0.108 \\
$10 \mu \mathrm{g} / \mathrm{mL}$ & 0.113 \\
$20 \mu \mathrm{g} / \mathrm{mL}$ & 0.119 \\
\hline a) Values are the means of two independent measurements that varied by \\
$<5 \%$.
\end{tabular}

In conclusion, we have described an anti- $H$. pylori effect exhibited by 5-methoxy-3,4dehydroxanthomegnin associated with antioxidant activity due to interference with the neutrophil respiratory burst. These results suggest that 5-methoxy3,4-dehydroxanthomegnin (1) exerts a protective effect, inhibiting the synergistic mechanism by which $H$. pylori and neutrophils cause gastric mucosal damage.

\section{Acknowledgments}

The authors are grateful to FAPESP, CNPq and PADC-UNESP for financial support.

\section{References}

Allen LH, Beecher BR, Lynch JT, Rohner OV, Wittine LM 2005. Helicobacter pylori disrupts NADPH oxidase targeting in human neutrophils to induce extracellular superoxide release. J Immunol 174: 3658-3667.

Allen LH, McCaffrey RL 2007. To activate or not to activate: distinct strategies used by Helicobacter pylori and Francisella tularensis to modulate the NADPH oxidase and survive in human neutrophils. Immunol Rev 219: 103-117.

Arend A, Loime L, Roosaar P, Soom M, Lõivukene K, Sepp E, Aunapuu M, Zilmer K, Selstam G, Zilmer M 2005. Helicobacter pylori substantially increases oxidative stress in indomethacin-exposed rat gastric mucosa. Medicina (Kaunas) 41: 343-347.

Bagchi D, McGinn TR, Ye X, Bagchi M, Krohn RL, Chatterjee A, Stohs SJ 2002. Helicobacter pylori-induced oxidative stress and DNA damage in a primary culture of human gastric mucosal cells. Dig Dis Sci 47:14051412.

Barile FA 1994. Introduction to in vitro cytotoxicology: mechanisms and methods. Boca Raton: CRC Press.

Bonacorsi C, Raddi MSG, Carlos IZ, Sannomiya M, Vilegas $\mathrm{W}$ 2009. Anti-Helicobacter pylori activity and immunostimulatory effect of extracts from Byrsonima crassa Nied. (Malpighiaceae). BMC Complem Altern M 9: 1-7.

Ching T, Jong J, Bast A 1994. A method for screening hypochlorous acid scavengers by inhibition of the oxidation of 5-thio-2-nitrobenzoic acid: application to anti-asthmatic drugs. Anal Biochem 218: 377-381.

Cowan MM 1999. Plant products as antimicrobial agents. Clin Microbiol Rev 12: 564-582.

Ding S, Minohara Y, Fan XJ, Wang J, Reyes VE, Patel J, Dirden-Kramer B, Boldogh I, Ernst PB, Crowe SE 2007. Helicobacter pylori infection induces oxidative stress and programmed cell death in human gastric epithelial cells. Infect Immun 75: 4030-4039.

Duynhoven YTHP, Rob de Jonge R 2001. Transmission of Helicobacter pylori: a role for food? WHO 79: 455460.

Ernst P 1999. Review article: the role of inflammation in the pathogenesis of gastric cancer. Aliment Pharm Ther 13: 13-18.

Freshney RI 1994. Culture of animal cells: a manual of basic techinique. 3rd. New York: Wiley-Liss.

Funatogawa K, Hayashi S, Shimomura H, Yoshida T, Hatano T, Ito H, Hirai Y 2004. Antibacterial activity of hydrolyzable tannins derived from medicinal plants 
against Helicobacter pylori. Microbiol Immunol 48: 251-261.

Hirayama O, Takagi M, Hukumoto K, Katoh S 1997. Evaluation of antioxidant activity by chemiluminescence. Anal Biochem 247: 237-241.

Howden CW, Hunt RH 1998. Guidelines for the management of Helicobacter pylori infection. Am J Gastroenterol 93: 2330-2338.

Huang S, Kuo H, Hsiao C, Lin Y 2002. Efficient synthesis of redox-switched naphthoquinone thiol-crown ethers and their biological activity evaluation. Bioorgan Med Chem 10: 1947-1952.

Kitagawa RR, Raddi MSG, Khalil NM, Vilegas W, Fonseca LM 2003. Effect of the isocoumarin paepalantine on the luminol and lucigenin amplified chemiluminescence of rat neutrophils. Biol Pharm Bull 26: 905-908.

Kitagawa RR, Raddi MSG, Santos LC, Vilegas W 2004. A new cytotoxic naphthoquinone from Paepalanthus latipes. Chem Pharm Bull 52: 1487-1488.

Marshall K, Reiter RJ, Poeggeler B, Aruoma OI, Halliwell B 1996. Evaluation of the antioxidant activity of melatonin in vitro. Free Radical Bio Med 21: $307-$ 315.

Mosmann T 1983. Rapid colorimetric assay for cellular growth and survival: application to proliferation and cytotoxicity assays. J Immunol Methods 65: 55-63.

Naito Y, Yoshikawa $\mathrm{T}$ 2002. Molecular and cellular mechanisms involved in Helicobacter pylori-induced inflammation and oxidative stress. Free Radical Bio Med 33: 323-336.

Nostro A, Cellini L, Di Bartolomeo S, Di Campli E, Grande R, Cannatelli MA, Marzio L, Alonzo V 2005. Antibacterial effect of plants extracts against Helicobacter pylori. Phytother Res 19: 198-202.

Parij N, Nagy AM, Fondu P, Neve J 1998. Effects of nonsteroidal anti-inflammatory drugs on the luminol and lucigenin amplified chemiluminescence of human neutrophils. Eur J Pharmacol 352: 299-305.

Park B, Lee H, Lee S, Piao X, Takeoka GR, Wong RY, Ahn Y, Kim J 2006. Antibacterial activity of Tabebuia impetiginosa Martius ex DC (Taheebo) against Helicobacter pylori. J Ethnopharmacol 105: 255262.

Pastene E, Speisky H, Troncoso M, Alarcón J, Figueroa G 2009. In vitro inhibitory effect of apple peel extract on the growth of Helicobacter pylori and respiratory burst induced on human neutrophils. J Agr Food Chem 57: 7743-7749.

Prior RL, Cao G 1999. In vivo total antioxidant capacity: comparison of different analytical methods. Free
Radical Bio Med 27: 1173-1181.

Shin JE, Kim JM, Bae EA, Hyun YJ, Kim DH 2005. In vitro inhibitory effect of flavonoids on growth, infection and vacuolation of Helicobacter pylori. Planta Med 71: 197-201.

Smoot DT, Elliott TB, Verspaget HW, Jones D, Allen CR, Vernon KG, Bremner T, Kidd LCR, Kim KS, Groupman JD, Ashktorab H 2000. Influence of Helicobacter pylori on reactive oxygen-induced gastric epithelial cell injury. Carcinogenesis 21: 2091-2095.

Stege PW, Davicino RC, Veja AE, Casali YA, Correa S, Micalizzi B 2006. Antimicrobial activity of aqueous extracts of Larrea divaricata Cav (jarilla) against Helicobacter pylori. Phytomedicine 13: 724-727.

Stites DP 1994. Clinical laboratory methods for detection of cellular immunity. In: Stites DP, Terr, AI, Parslow TG. Basic clinical immunology. 8 th ed. Norwalk: Appleton \& Lange, p 195-215.

Trush MA 1987. Chemiluminescence as a probe to investigate chemical-cell interactions: a toxicologicol perspective. In: Dyke KV, Castranova V. Cellular chemiluminescence. Boca Raton: CRC Press, v. 3, p 185-205.

Wang C, Liu Y, Du S, Lin C, Fu H 2008. Helicobacter pylori neutrophil-activating protein promotes myeloperoxidase release from human neutrophils. Biochem Bioph Res Co 377: 52-56.

Wang YC, Li WY, Wu DC, Wang JJ, Wu CH, Liao JJ, Lin CK 2011. In vitro activity of 2 -methoxy-1,4naphthoquinone and stigmasta-7,22-diene-3 $\beta$-ol from Impatiens balsamina L. against multiple antibioticresistant Helicobacter pylori. Evid-Based Compl Alt Medicine DOI: 10.1093/ecam/nep 147 (SCI).

Yildiz G, Demiryürek T 1998. Ferrous iron-induced luminol chemiluminescence: a method for hydroxyl radical study. J Pharmacol Toxicol 39: 179-184.

Zaidi SFH, Yamada K, Kadowaki M, Usmanghani K, Sugiyama T 2009. Bactericidal activity of medicinal plants, employed for the treatment of gastrointestinal ailments, against Helicobacter pylori. J Ethnopharmacol 121: 286-291.

\section{*Correspondence}

Rodrigo Rezende Kitagawa

Departamento de Ciências Farmacêuticas, Universidade Federal do Espírito Santo

Avenida Marechal Campos 1468, 29040-090, Vitória-ES, Brazil

rodrigo.kitagawa@ufes.br

Tel: +552733357293 